Revista Oficial del Poder Judicial

ÓRGANO DE INVESTIGACIÓN DE LA CORTE SUPREMA DE JUSTICIA DE LA REPÚBLICA DEL PERÚ

Vol. 9, n. 11 , enero-junio, 2019, 457-459

ISSN versión impresa: 1997-6682

ISSN versión electrónica: 2663-9130

DOI: hltps://doi.org/10.35292/ropj.u9i11.16

\title{
Enrique López Albújar Obras completas. Narrativa.
}

Tomo I, 2 volúmenes. Lima: Fondo Editorial del Poder Judicial, 2018, 600 pp. (uol. 1) y 692 pp. (uol. 2)

$\$ 0$

La reciente aparición de los dos volúmenes de la narrativa completa de Enrique López Albújar (que componen el primer tomo de sus Obras completas, que se reunirán en seis tomos), editados por el Fondo Editorial del Poder Judicial del Perú, es un buen motivo para retomar la discusión en torno al valor de la obra del destacado chiclayano.

Vista por Mariátegui, la narrativa de López Albújar sirve a los intereses políticos del indigenismo. En otras palabras, quiere probar, con los cuentos del autor de Matalaché, la histórica vinculación de nuestras prácticas culturales indígenas con el comunismo y con el proyecto de la revolución socialista.

La lectura mariateguiana de la obra de López Albújar, sin duda, se postula como un acto de fundación crítico que busca instaurar las bases de una praxis indigenista alejada de los paternalismos y exotismos que venían contaminando la representación del indio hasta entonces. Sin embargo, este acto de fundación no puede 


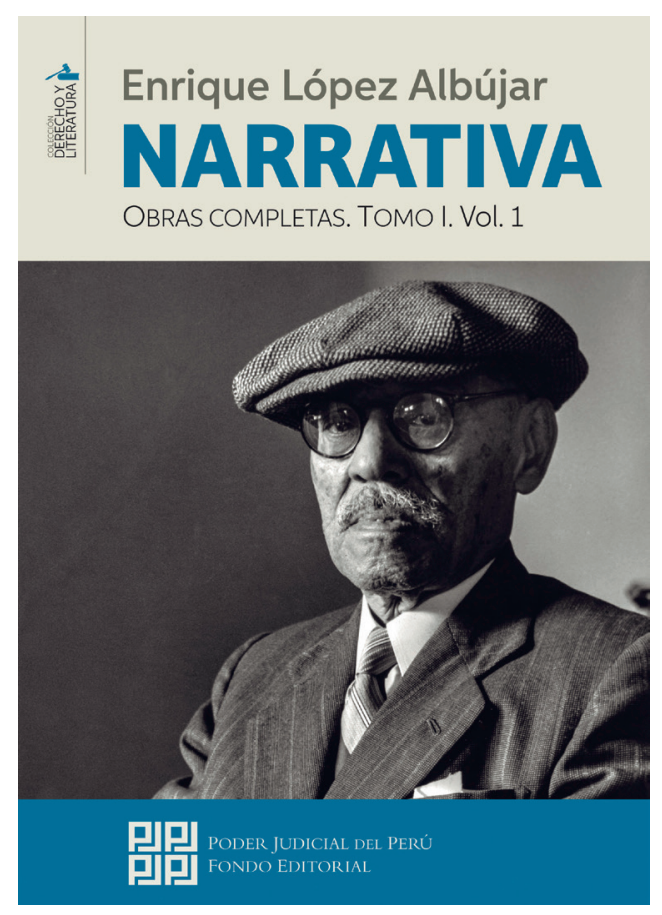

dejar de ser visto, a la vez, como un acto que, desde el campo político, utiliza polémicamente a la literatura de López Albújar para reactualizar formas de socialización comunitarias incas como una prueba de la viabilidad del proyecto comunista en el Perú. Citamos a Mariátegui porque, debido a su lectura, tenemos a López Albújar como uno de los padres del indigenismo peruano, propuesta que, por lo menos, debería ser revisada.

Otro aspecto que debe atenderse es el de la relación del autor con el universo judicial. Aquí valdría la pena mencionar que, como escritor de su época, López Albújar asumió los principios del positivismo filosófico y del naturalismo literario. Siguiendo sus postulados, su actitud como escritor se afirmó, como quería Zola, en la del «moralista experimentador que demuestra por la experiencia cómo se comporta una pasión en un medio social». Este interés es llevado por nuestro escritor a los Andes y lo convierte en un descriptor de pasiones, de temperamentos, de estados en los que la violencia y el crimen asumen el papel protagónico. López Albújar debió haber leído, sin duda, el manifiesto zoliano titulado «La novela experimental» de 1880 .

Zola reconoce que el trabajo del escritor naturalista es el más noble y de más amplia aplicación: «Ser amo del bien y del mal, regular la vida, regular la sociedad [...] aportar sobre todo bases sólidas para la justicia resolviendo por la experiencia las cuestiones de la criminalidad...». Esta relación con el positivismo y el naturalismo 
deben tenerse en López Albújar como esenciales para entender su obra, dentro de la cual haber sido juez pasa a ser un elemento importante pero no decisivo. Es decir, podría no haber sido magistrado (los casos y las sentencias que emanan de ellos al final pasan a ser jurisprudencia y pueden ser consultados) y haber escrito su obra, pero no la hubiese escrito sin haber abrazado el positivismo filosófico y el naturalismo narrativo.

La edición, al cuidado de la doctora Gladys Flores Heredia, es seria, por el rigor con que emplea las ediciones conocidas de las obras del autor para establecer la versión definitiva. Con respecto al orden en que es presentada la obra, habría sido mejor el orden cronológico, de manera que pudiera observarse la evolución del escritor, es decir, desde sus inicios en el decadentismo literario, presente en La mujer Diógenes, pasando por el naturalismo de los Cuentos andinos hasta el realismo regionalista de sus últimos libros Cuentos de arena y soly La diestra de don Juan.

Se incluyen la presentación de Francisco Távara Córdova y la introducción de Duberlí Rodríguez Tineo, de enfoque judicial; y un estudio de Raúl Estuardo Cornejo de 1972. Se extraña, en esta dirección, una aproximación literaria más acorde con las nuevas investigaciones sobre el autor.

Jorge Valenzuela Garcés Universidad Nacional Mayor de San Marcos (Lima, Perú) Contacto: jualenzuelag@unmsm.edu.pe https://orcid.org/0000-0001-8886-699X 